\title{
Expression of leptin and leptin receptor isoforms in the human stomach
}

H Mix, A Widjaja, O Jandl, M Cornberg, A Kaul, M Göke, W Beil, M Kuske, G Brabant, M P Manns, S Wagner

\begin{abstract}
Background-Leptin is an important regulator of food intake and energy expenditure. Initially it was thought to be expressed exclusively in and secreted by adipocytes. Recently, leptin expression was also noted in other tissues, including rat gastric mucosa. Information on leptin and leptin receptor expression in the human stomach is lacking.

Aim-To investigate expression of leptin and its corresponding receptors in human gastric epithelial cells.

Methods-Fundic and antral gastric mucosal biopsies, primary cultures of human gastric epithelial cells, and the human gastric cancer cell line AGS were screened for expression of leptin and different leptin receptor isoform mRNA by reverse transcriptase-polymerase chain reaction. Immunohistochemistry was performed for localisation of leptin and leptin receptor proteins in gastric mucosa.

Results-mRNA of leptin and its four receptor isoforms (huOB-R, long receptor isoform; huB219.1-3, short receptor isoforms) was detected in gastric mucosal biopsies, cultured human gastric epithelial cells, and gastric cancer cells. Immunohistochemistry demonstrated that chief as well as parietal cells were reactive to leptin and leptin receptors.

Conclusions-Leptin and leptin receptors are expressed in human gastric mucosa. These findings suggest a paracrine and/or autocrine effect of leptin on gastric epithelial cell function.

(Gut 2000;47:481-486)
\end{abstract}

Keywords: leptin; leptin receptor isoforms; immunohistochemistry; gastric mucosa

Pharmacology,

Medizinische

Hochschule Hannover, Germany

W Beil

Institute for Pathology,

Medizinische

Hochschule Hannover,

Germany

M Kuske

Correspondence to:

Dr S Wagner, Department of

Gastroenterology and

Hepatology, Medizinische

Hochschule Hannover,

Carl-Neuberg-Str. 1, 30625

Hannover, Germany. Email:

wagner.siegfried@

mh-hannover.de

Accepted for publication 8 February 2000 haematopoiesis, in the control of reproductive status, and as a promoter of angiogenesis).$^{6-14}$ In 1998, Bado et al found leptin expression in the rat gastric epithelium ${ }^{15}$ and postulated that the leptin system may be involved in the regulation of cholecystokinin mediated control of food intake.

Sequencing analysis of the leptin receptor revealed a single membrane spanning receptor of the class I cytokine receptor family, with the closest relatives in the gp130 receptor, the G-CSF receptor, and the leukaemia inhibitory factor receptor. ${ }^{16-18}$ Further screening and analysis of cDNA libraries exposed four human receptor isoforms, including a long form with an intracellular domain of 303 amino acids, containing sequence motifs of signal transducing capabilities, and three short forms, arising from alternative RNA splicing at the C terminal coding exon. Furthermore, a transcript missing the transmembrane domain suggests the existence of a soluble form of the receptor. ${ }^{19}$

Analysis of tissue distribution of leptin receptor mRNA in rodents demonstrated high levels in the choroid plexus, lung, and kidney, in addition to somewhat lower levels in nearly all tissues. ${ }^{2}$ Further mRNA investigations showed that the short receptor isoforms were much more abundant than the long isoform. No published data are available on leptin and leptin receptor expression in the human stomach and hence we sought to determine if leptin and its corresponding receptors are expressed in the human stomach.

\section{Materials and methods}

BIOPSY OF HUMAN GASTRIC MUCOSA

Samples of fundic and antral mucosa were obtained from subjects with histologically verified normal gastric mucosa who had undergone gastroscopy for evaluation of gastrointestinal symptoms. All patients gave informed consent. Biopsied samples were snap frozen in liquid nitrogen for RNA extraction and preparation of cryostat sections using Tissue-Tek embedding, or fixed in $4 \%$ formaldehyde solution for paraffin wax embedding.

ISOLATION OF HUMAN GASTRIC EPITHELIAL CELLS Human gastric epithelial cells were isolated from gastric tissue specimens obtained during gastric surgery as described previously. ${ }^{20} 21$

Abbreviations used in this paper: FITC, fluorescein isothiocyanate; huOB-R, human long leptin receptor isoform; huB2 19.1-huB219.3, human short leptin receptor isoforms; RT-PCR, reverse transcriptase-polymerase chain reaction; BSA, bovine serum albumin. 
Table 1 Primers used to detect house keeping gene GAPDH, leptin, and different splice variants of the leptin receptor gene

\begin{tabular}{|c|c|c|c|}
\hline Primer name & Sequence 5'-3' & Length & Product size \\
\hline GAPDH forward & ggT $\bullet$ Cgg $\bullet a g T \cdot C a a \cdot C g g \bullet a T T \cdot T g g \bullet T C g$ & 24 & \\
\hline GAPDH reverse & $\mathrm{CCT} \cdot \mathrm{CCg} \cdot \mathrm{aCg} \cdot \mathrm{CCT} \cdot \mathrm{gCT} \cdot \mathrm{TCa} \cdot \mathrm{CCa} \cdot \mathrm{C}$ & 22 & 782 \\
\hline Leptin forward & $\mathrm{CCa} \cdot a g a \cdot \mathrm{Tgg} \bullet \mathrm{aCC} \cdot \mathrm{aga} \cdot \mathrm{CaC} \cdot \mathrm{Tg}$ & 20 & \\
\hline Leptin reverse & $\mathrm{gCC} \cdot \mathrm{aCC} \cdot \mathrm{aCC} \cdot \mathrm{TCT} \cdot \mathrm{gTg} \cdot \mathrm{gag} \cdot \mathrm{Ta}$ & 20 & 220 \\
\hline Leptin receptor forward & $\mathrm{TTg} \cdot \mathrm{TgC} \cdot \mathrm{Cag} \bullet \mathrm{Taa} \cdot \mathrm{TTa} \cdot \mathrm{TTT} \cdot \mathrm{CCT} \cdot \mathrm{CTT}$ & 24 & \\
\hline Reverse primer: universal & $\mathrm{aTa} \bullet \mathrm{gCT} \cdot \mathrm{TTT} \bullet \mathrm{TCa} \cdot \mathrm{TTC} \cdot \mathrm{TTT} \bullet \mathrm{ggT} \cdot \mathrm{gTg}$ & 24 & 78 \\
\hline Reverse primer: huB219.1 & $\mathrm{CTg} \cdot \mathrm{Tgg} \bullet \mathrm{CCT} \cdot \mathrm{TCC} \cdot \mathrm{gCa} \bullet \mathrm{gTg}$ & 18 & 227 \\
\hline Reverse primer: huB219.2 & $\mathrm{aCC} \cdot \mathrm{TCC} \cdot \mathrm{aCC} \cdot \mathrm{Cag} \cdot \mathrm{Tag} \cdot \mathrm{TTC} \cdot \mathrm{CTT}$ & 21 & 176 \\
\hline Reverse primer: huB219.3 & $\mathrm{agT} \cdot \mathrm{Tgg} \cdot \mathrm{CaC} \cdot \mathrm{aTT} \cdot \mathrm{ggg} \cdot \mathrm{TTC} \cdot \mathrm{aT}$ & 20 & 200 \\
\hline Reverse primer: huOB-R & CTg•aTC $\bullet a g C \cdot g T g \bullet g C g \bullet T a T \cdot T T$ & 20 & 439 \\
\hline
\end{tabular}

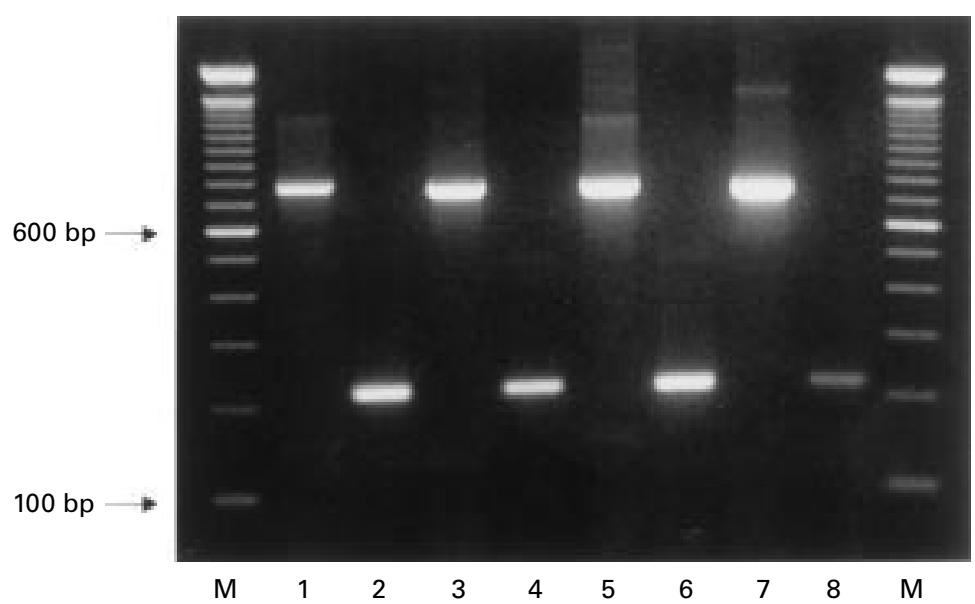

Figure 1 Detection of leptin $m R N A$ by reverse transcriptase-polymerase chain reaction (RT-PCR). Lanes 1+2, adipose tissue; lanes 3+4, human gastric mucosal biopsy; lanes $5+6$, primary cultured human gastric epithelial cells; lanes $7+8$, human cancer cell line AGS. The PCR products of leptin specific $m R N A$ are demonstrated in lanes $2,4,6$, and 8 . Lanes 1, 3, 5, and 7 show the house keeping gene GAPDH. M, size marker 100 bp DNA ladder.

Informed consent was obtained from each patient, according to the revised version of the Declaration of Helsinki. In addition, the study was approved by the local ethics committee of the Medizinische Hochschule Hannover. Surgical specimens (3-10 g mucosa wet mass) were taken immediately after surgical removal from a macroscopically unaffected part of the stomach and placed in $25 \mathrm{ml}$ of medium $\mathrm{I}$, containing $70 \mathrm{mmol} / \mathrm{l} \quad \mathrm{NaCl}, \quad 20 \mathrm{mmol} / 1$ $\mathrm{NaHCO}_{3}, 1.5 \mathrm{mmol} / \mathrm{l} \quad \mathrm{Na}_{2} \mathrm{HPO}_{4}, 5 \mathrm{mmol} / \mathrm{l}$ $\mathrm{KCl}, 1.5 \mathrm{mmol} / 1 \mathrm{MgCl}_{2}, 1 \mathrm{mmol} / 1 \mathrm{CaCl}_{2}$, $11 \mathrm{mmol} / 1$ glucose, and $50 \mathrm{mmol} / 1$ HEPES. Gastric mucosa was scraped off, cut into small pieces, and suspended in medium I. The mucosal material was centrifuged $(200 \mathrm{~g}$, five minutes) and resuspended in $40 \mathrm{ml}$ of medium I supplemented with $40 \mathrm{mg}$ of collagenase (from Clostridium histolyticum; Boehringer Mannheim, Mannheim, Germany). The suspension was preincubated for seven minutes at $37^{\circ} \mathrm{C}$ while stirring. The suspension was then sedimented (200 g, eight minutes) and incubated in $40 \mathrm{ml}$ of medium I supplemented with $24 \mathrm{mg}$ of pronase (from Streptomyces griseus; Boehringer Mannheim), $40 \mathrm{mg}$ of collagenase, $20 \mathrm{mg}$ of hyaluronidase (Sigma Chemical Co., St Louis, Missouri, USA), and $0.2 \%$ bovine serum albumin (BSA). Enzyme digestion was stopped after 20 minutes, cells were filtered through a nylon cloth $(60 \mu \mathrm{m})$, and washed three times in medium I supplemented with $0.2 \%$ BSA. Isolated cells were resuspended in RPMI 1640 medium (Gibco Karlsruhe, Ger- many). The number and viability of cells were determined by trypan blue exclusion $(0.04 \%$ trypan blue; Gibco).

CELL CULTURE

Human gastric epithelial cells were incubated in rat tail collagen coated $250 \mathrm{ml}$ plastic flasks (Greiner, Nürtingen, Germany). Approximately $10 \times 10^{6}$ cells were used per $250 \mathrm{ml}$ flask containing RPMI 1640 supplemented with $10 \%$ heat inactivated fetal calf serum, gentamicin $(100 \mu \mathrm{g} / \mathrm{ml})$, penicillin $(100 \mathrm{IU} / \mathrm{ml})$, and amphotericin B $(2.5 \mu \mathrm{g} / \mathrm{ml})$. The flasks were incubated at $37^{\circ} \mathrm{C}$ in air enriched with $5 \%$ $\mathrm{CO}_{2}$ at $100 \%$ humidity. In addition to gastric epithelial cell primary cultures, similar studies were performed using the human gastric cancer cell line AGS (ATCC). Cell culture conditions were the same as described for culture of primary gastric epithelial cells, except for the use of amphotericin B.

RNA ISOLATION

Total RNA was extracted from (i) 2-4 day old gastric epithelial cell primary cultures incubated in $250 \mathrm{ml}$ plastic flasks, (ii) a confluent monolayer of AGS cells, and (iii) biopsy samples of human gastric mucosa using a commercial RNA isolation kit (Qiagen RNeasy, Hilden, Germany). In addition, RNA was extracted from human adipose tissue obtained from the omentum majus during gastric surgery as well as from human placenta, obtained immediately post partum. RNA from adipose tissue and placenta was used as a positive control for leptin and leptin receptor expression.

REVERSE TRANSCRIPTASE-POLYMERASE CHAIN REACTION (RT-PCR)

Up to $5 \mu \mathrm{g}$ of total RNA were transcribed to cDNA using $200 \mathrm{U}$ of Superscript RTase (Life Technologies, Karlsruhe, Germany), $5 \mathrm{nmol}$ of dNTP (dATP, dTTP, dCTP, dGTP), 10 pmol of oligo(dT) $)_{12-18}$ (Pharmacia, Freiburg, Germany), $0.2 \mu \mathrm{mol}$ of dithiothreitol, $2 \mu \mathrm{l} 10 \times$ reaction buffer (Life Technologies), $20 \mathrm{U}$ of RNasin (Promega, Mannheim, Germany), and distilled, deionised water in a $20 \mu \mathrm{l}$ reaction volume. The reaction mixture was incubated at $37^{\circ} \mathrm{C}$ for 60 minutes and terminated by heating at $90^{\circ} \mathrm{C}$ for five minutes. A total of $500 \mathrm{ng}$ of cDNA were used per PCR reaction. The PCR reaction mixtures (50 $\mu \mathrm{l}$ final volume) contained: $20 \mathrm{mmol} / 1$ Tris $\mathrm{HCl}$ ( $\mathrm{pH} 8.0$ ), $50 \mathrm{mmol} / \mathrm{l} \mathrm{KCl}, 1.5 \mathrm{mmol} / 1$ $\mathrm{MgCl}_{2}, 0.2 \mathrm{mmol} / 1$ of each of the four dNTPs, $0.25 \mu \mathrm{mol} / 1$ of each primer, and $2.5 \mathrm{U}$ of Taq Polymerase (Life Technologies). The reaction mixtures were incubated in a thermal cycler (Robocycler Gradient 96; Stratagene, La Jolla, California, USA) for 35 cycles under the following conditions (denaturation, annealing, extension): $94^{\circ} \mathrm{C}$ for 30 seconds, $60^{\circ} \mathrm{C}$ for 30 seconds, and $72^{\circ} \mathrm{C}$ for one minute, followed by 10 minutes at $72^{\circ} \mathrm{C}$.

Oligonucleotide primer pairs used in this study are listed in table 1 . The leptin specific primer pair was designed using the software Primer3 (http://www-genome.wi.mit.edu/cgibin/primer/primer3). Oligonucleotides specific for leptin receptor isoforms described 

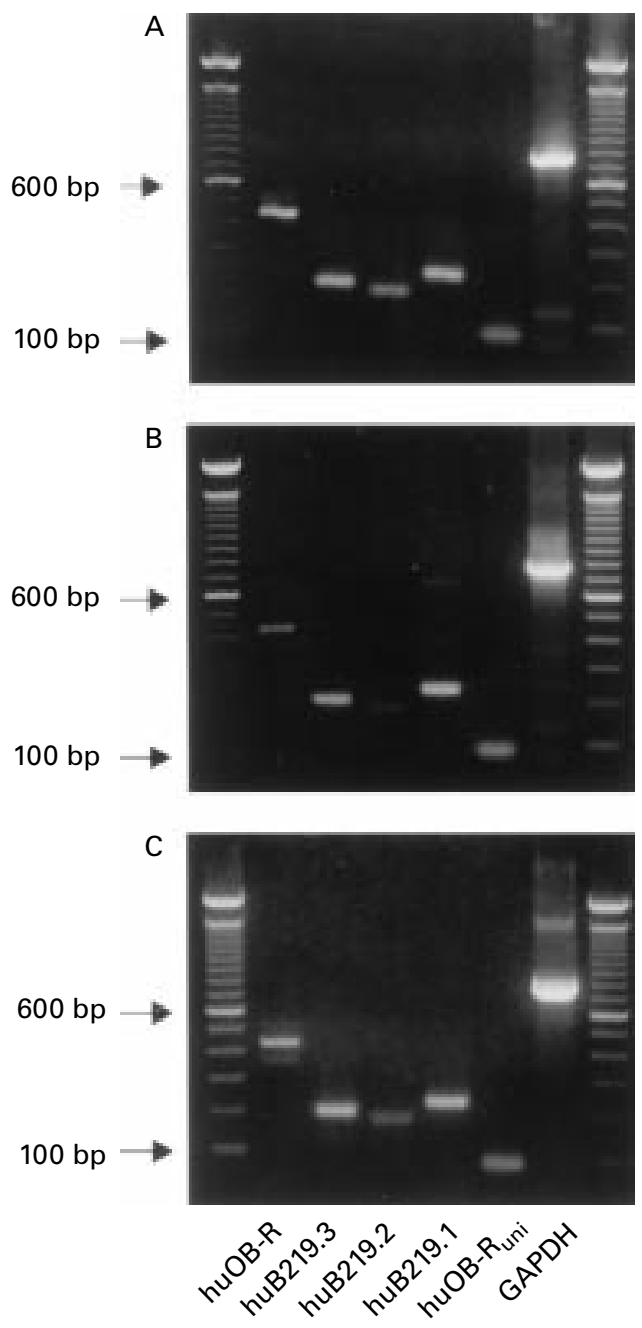

Figure 2 Detection of different leptin receptor $m R N A$ splice variants by reverse transcriptase-polymerase chain reaction (RT-PCR). (A) Human gastric mucosal biopsy. (B) Primary cultured human gastric epithelial cells. (C) Human cancer cell line AGS. huOB-R, human long leptin receptor isoform; huB219.1-huB219.3, human short leptin receptor isoforms, $h u O B-R_{u n}$, primers chosen to detect all receptor isoforms.

previously ${ }^{22}$ identified the long receptor isoform huOb-R and three short receptor isoforms huB219.1-huB219.3. The primer pair universal can detect all isoforms. PCR products were separated by electrophoresis on a $1.8 \%$ agarose gel stained with ethidium bromide. The specificity of the amplified PCR products was confirmed by restriction enzyme analysis.

IMMUNOHISTOCHEMISTRY

Paraffin wax embedded material was used for peroxidase staining of leptin and leptin receptors, while cryostat sections were used for immunohistochemical double staining. Cryostat sections $(7 \mu \mathrm{m})$ were fixed in acetone for 10 minutes and processed as described for paraffin sections. Sections of paraffin wax embedded gastric mucosal biopsies $(4 \mu \mathrm{m})$ were deparaffinised in xylene and rehydrated before analysis. Endogenous peroxidase was quenched with $3 \%$ hydrogen peroxide in water for 10 minutes. The slides were then blocked for 30 minutes with phosphate buffered saline supplemented with $1 \%$ BSA. Blocking was followed by overnight incubation at $4^{\circ} \mathrm{C}$ with primary antibodies diluted 1:75 for detection of leptin (Ob-A20 sc-842, Santa Cruz Biotechnology, Santa Cruz, California, USA), 1:100 dilution for leptin receptors (Ob-R H-300 sc-8325, Ob-R M-18 sc-1834, and Ob-R B-3 sc-8391, Santa Cruz Biotechnology), and $1: 125$ dilution for detection of pepsinogen (polyclonal antibody, raised in rabbits, provided by Professor Foltmann, University of Copenhagen, Copenhagen, Denmark). Localisation of primary antibody binding was detected using biotinylated secondary antibody, streptavidin conjugated horseradish peroxidase, and 3-amino-9-ethylcarbazol substrate, contained within the Histostain-Plus kit (Zymed Laboratories, Inc., San Francisco, California, USA). In the case of goat antihuman leptin receptor antibody, a donkey antigoat biotinylated secondary antibody (Dianova, Hamburg, Germany) was used diluted 1:200 to detect primary antibody localisation. The blocking peptides for leptin and leptin receptor antibodies (Santa Cruz Biotechnology) were added as $10 \mu \mathrm{g} / \mathrm{ml}$ during primary antibody incubation as a direct competitive control for antibody specificity. Omission of the primary antibodies exhibited no immunostaining.

For identification of gastric epithelial cell types which express leptin and leptin receptors, immunofluorescence double labelling was performed using antibodies against pepsinogen (1:125), parietal cells (human serum of an antiparietal cell positive patient $(1: 80))$, gastric mucin (rabbit polyclonal antibody h-MG (1:2000), kindly provided by Jan Dekker, Rotterdam, the Netherlands), or chromogranin A (1:125, Dako, Hamburg, Germany) and the pertinent antibodies for leptin and leptin receptors. Localisation of primary antibody binding was detected by species specific fluorescein isothiocyanate (FITC) conjugated secondary antibodies $(1: 200)$ and rhodamine conjugated secondary antibodies (1:200) which were species different. For identification of leptin in parietal cells, a combination of peroxidase and FITC staining was used. Analysis of cells was undertaken using a fluorescence microscope (Olympus BX 60). Numbers of leptin and leptin receptor immunoreactive cells were determined in fundic and antral specimens of the same subject and expressed as a percentage of total epithelial cell numbers of the gastric glands. A minimum of 400 cells were counted in randomly selected fields. Data are mean (SD) from three different subjects.

\section{Results}

MRNA EXPRESSION OF LEPTIN IN THE HUMAN GASTRIC MUCOSA

Expression of the obese gene (leptin) in the human stomach was analysed by RT-PCR using a specific primer pair (table 1) deduced from the cloned human obese gene ${ }^{23}$ yielding a 220 bp PCR product (fig 1). Leptin mRNA expression was detected in gastric mucosal biopsies, primary cultured gastric epithelial cells, and the human gastric cancer cell line 

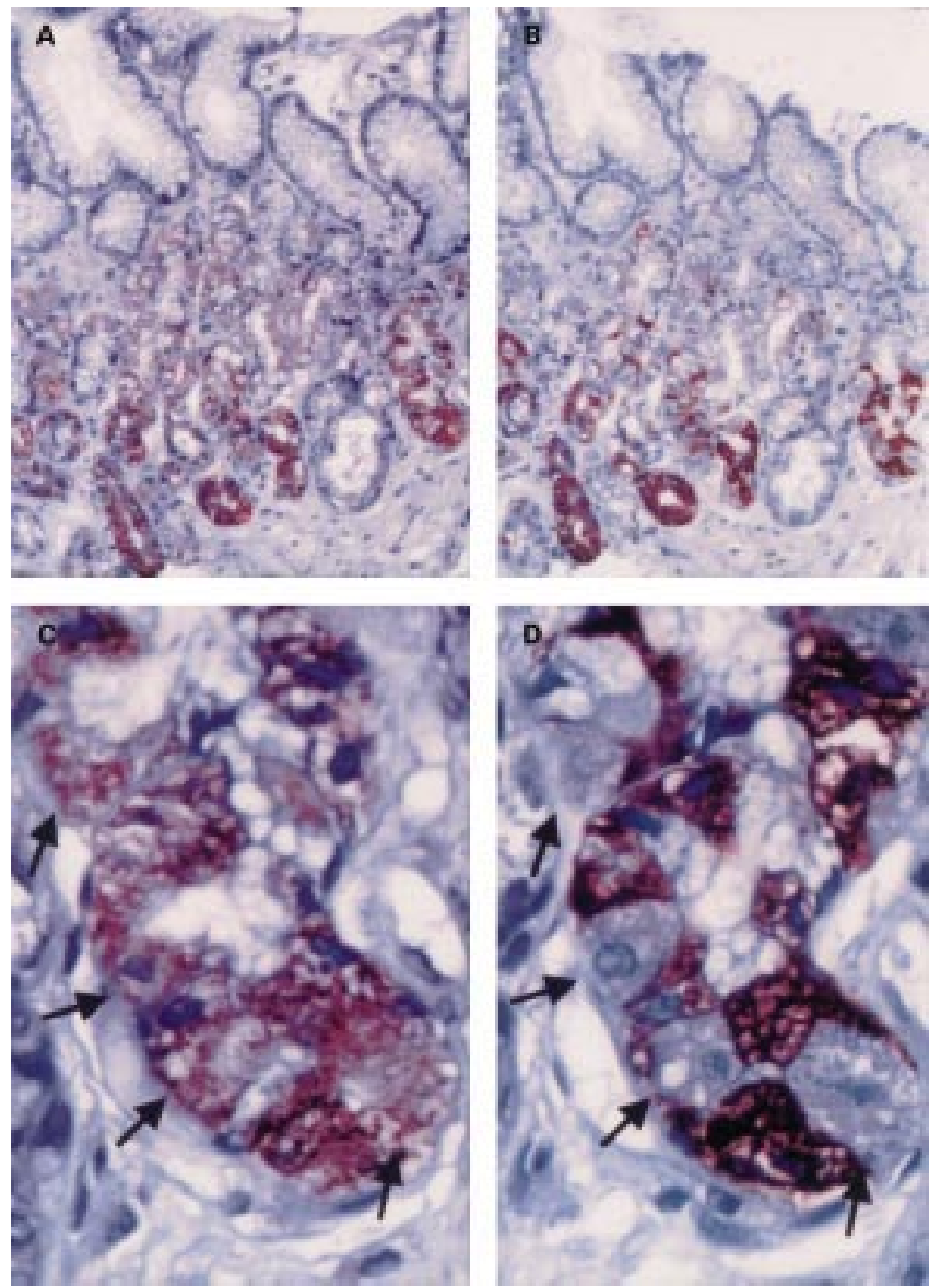

Figure 3 Immunohistochemical detection of leptin $(A, C)$ and pepsinogen $(B, D)$ in serial sections of human fundic mucosal biopsies. $(A, B)$ Overview (original magnification $\times 100)$. (C, D) Detailed view (original magnification $\times 400$ ). Arrows denote corresponding cells of adjacent sections which are leptin positive and pepsinogen negative. Paraffin embedded, formalin fixed tissue sections were analysed using a streptavidin-peroxidase technique as described under materials and methods.

AGS. To confirm specificity of the amplified PCR product, restriction enzyme analysis was performed using BsaI which exhibited the expected fragments of $164 \mathrm{bp}$ and $56 \mathrm{bp}$ (data not shown).

MRNA EXPRESSION OF LEPTIN RECEPTOR ISOFORMS IN THE HUMAN GASTRIC MUCOSA Gastric mucosa and cultured gastric epithelial cells were screened for expression of already identified leptin receptor isoforms. All gastric specimens demonstrated the three short receptor isoforms huB219.1-huB219.3 as well as the long receptor isoform huOB-R (fig 2). Although PCR is not a quantitative measurement of gene expression, the PCR product of the short leptin receptor isoform huB219.2 exhibited a weaker signal compared with the other isoforms, especially in primary cultured epithelial cells.

LEPTIN PROTEIN EXPRESSION IN THE HUMAN GASTRIC MUCOSA

Using affinity purified rabbit polyclonal antibodies raised against an epitope mapping at the

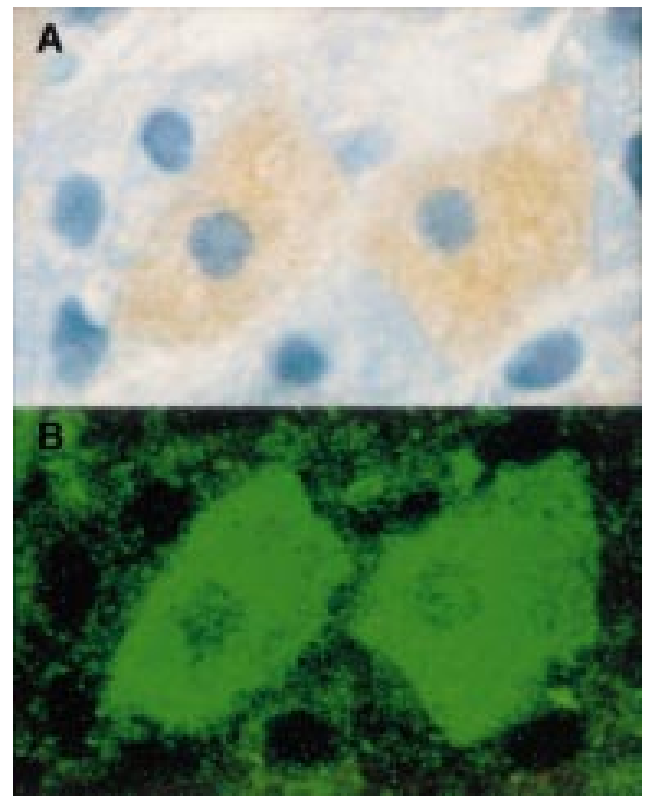

Figure 4 Double immunostaining for leptin $(A)$ and parietal cell antigen (B) in human fundic gastric mucosa (original magnification $\times 1000$ ). Paraffin embedded, formalin fixed tissue sections were analysed using a streptavidin-peroxidase technique $(A)$ and FITC labelled immunofluorescence (B) as described in materials and methods.

carboxy terminus of the obese gene product (leptin), strong immunostaining was seen in the lower half of gastric glands (fig 3A). Since this site is similar to that of the pepsinogen secreting chief cells, immunostaining of chief cells was performed in serial adjacent sections (fig 3B). These studies confirmed that pepsinogen immunoreactive cells also possessed leptin immunoreactivity (fig 3C, D). However, leptin immunoreactivity was also found in pepsinogen negative epithelial cells but to a lesser extent. The site and morphology of these cells were reminiscent of parietal cells, therefore immunofluorescence double labelling with FITC conjugated antiparietal cell antibodies was performed which disclosed coexpression of leptin and parietal cell antigens in the same cells (fig 4). Surface mucous cells did not show immunostaining of leptin. Fundic and antral mucosa showed a similar glandular distribution of leptin immunoreactivity but the percentage of leptin positive cells was higher in the fundic region (31 (6)\%) than in the antrum (10 (1) $\%)$.

LEPTIN RECEPTOR PROTEIN EXPRESSION IN THE HUMAN GASTRIC MUCOSA

Leptin receptor immunoreactivity was predominantly detected in the midregion and lower part of the gastric glands using a polyclonal antibody with binding specificity to an amino acid sequence mapping at the conserved intracellular region (amino acids 879-896, Ob-R M-18). This staining pattern resembled that of leptin immunoreactivity. Immunofluorescence double staining identified the chief and parietal cells as leptin receptor immunoreactive (fig 5). An antibody with binding specificity to an amino acid sequence mapping at the amino terminus (H-300, extracellular region) showed 

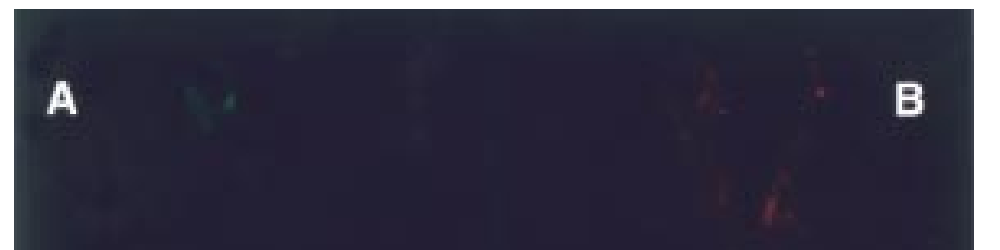

C

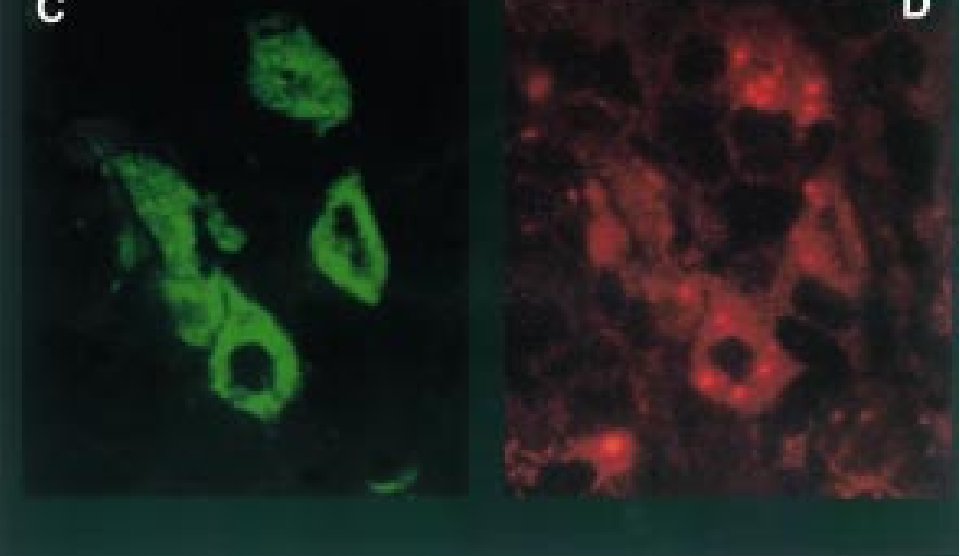

Figure $5(A, B)$ Double immunofluorescent staining for pepsinogen $(A$, green) and leptin receptor $(B$, red) in tissue sections of human fundic gastric mucosa (original magnification $\times 400$ ). Chief cells were identified by rabbit polyclonal antipepsinogen antibody (dilution $1: 125$ ) and FITC conjugated goat antirabbit IgG (dilution 1:100) in cryostat sections. Subsequently mouse monoclonal antileptin receptor IgG1 (B-3, dilution 1:50) and rhodamine conjugated goat antimouse IgG (dilution 1:100) were used. $(C, D)$ Double immunofluorescent staining for parietal cell antigen ( $C$, green) and leptin receptor $(D, r e d)$ in tissue sections of human fundic gastric mucosa (original magnification $\times 400$ ). Parietal cells were identified by serum of an antiparietal cell positive patient (dilution 1:80) and FITC conjugated goat anti-human IgG (dilution 1:50) in cryostat sections. Subsequently rabbit polyclonal antileptin receptor antibody $(\mathrm{H}-300$, dilution 1:50) and rhodamine conjugated goat antirabbit $\operatorname{IgG}$ (dilution 1:75) were used.

similar staining patterns to the M-18 antibody. Leptin receptor immunoreactivity varied in different cells of the same population and was higher in the fundic region (28 (3)\%) compared with the antrum $(9(1) \%)$.

\section{Discussion}

In this study we demonstrated that leptin and its corresponding receptor isoforms are expressed in the human stomach. Furthermore, we found that leptin and its receptors were localised within the gastric epithelial glands. Interestingly, both leptin and the leptin receptors are located in chief and parietal cells. Although it was not the aim of the present study to provide quantitative analysis on cellular leptin content, our immunohistochemical data suggest that chief cells are the primary source of leptin.

Using the RT-PCR procedure, we detected all four splice variants of the human leptin receptor which have been identified so far, including three short receptor isoforms (huB219.1-huB219.3) as well as the long receptor isoform (huOb-R). ${ }^{82}$ The homology of leptin receptors to class I cytokine receptors may provide important clues on signal transduction pathways. The JAK/STAT cascade has been identified as a signalling pathway for the long form of the leptin receptor. ${ }^{24}{ }^{25}$ In contrast, the short leptin receptor isoforms were found to be inactive in the STAT assays and thus may not have signal transducing capabilities. However, recent studies revealed that a short leptin receptor can also induce signal transduction. ${ }^{26}$ Moreover, all human and murine short receptor isoforms contain a box 1 sequence with the conserved $\mathrm{P} \times \mathrm{P}$ that is critical for JAK2 binding and intracellular signalling. ${ }^{8}$ Thus expression of different leptin receptor isoforms in the human stomach may indicate diverse physiological and pathophysiological roles of leptin in this tissue.

Although the postulated physiological actions of leptin are as yet unknown, recent findings in murine macrophages have shown stimulation of proinflammatory immune responses by leptin ${ }^{27}$ which suggests that leptin could play a role in gastric mucosal inflammation. In fact, our preliminary data in patients with Helicobacter pylori gastritis indicate that leptin expression is upregulated in $H$ pylori infection (unpublished data). Leptin may have further roles in epithelial cell physiology, including effects on regulation of pepsinogen and/or gastric acid secretion. This hypothesis is supported by coexpression of leptin and leptin receptors in gastric chief cells and parietal cells. However, gastric leptin have may not only local paracrine effects but also endocrine actions through portal vein drainage and central nervous system effects via stimulation of vagal afferents. ${ }^{28-30}$

In conclusion, we have demonstrated leptin and leptin receptor expression in chief and parietal cells of the human stomach. Coexpression of leptin and the corresponding leptin receptor suggests that gastric leptin may have a paracrine and/or autocrine function in the human stomach. The hitherto unknown physiological role of the leptin system in the human stomach needs to be defined in future studies.

1 Zhang Y, Proenca R, Maffei M, et al. Positional cloning of the mouse obese gene and its human homologue. Nature 1994;372:425-31.

2 Tartaglia L, Dembski $\mathrm{M}$, Weng X, et al. Identification and expression cloning of a leptin receptor, OB-R. Cell 1995;83:1263-71.

3 Senaris R, Garcia-Caballero T, Casabiell X, et al. Synthesis of leptin in human placenta. Endocrinology 1997;138:45014 .

4 Smith-Kirwin SM, O'Connor DM, Johnston J, et al. Leptin expression in human mammary epithelial cells and breast milk. F Clin Endocrinol Metab 1998;83:1810-13.

5 Potter JJ, Womack L, Mezey E, et al. Transdifferentiation of rat hepatic stellate cells results in leptin expression. Biochem Biophys Res Commun 1998;244:178-82.

6 Bennett BD, Solar GP, Yuan JQ, et al. A role for leptin and its cognate receptor in hematopoiesis. Curr Biol 1996;6: 1170-80.

7 Gainsford T, Willson TA, Metcalf D, et al. Leptin can induce proliferation, differentiation, and functional activation of hemopoietic cells. Proc Natl Acad Sci USA 1996;93: tion of hernor

8 Cioffi JA, Shafer AW, Zupancic TJ, et al. Novel B219/OB receptor isoforms: possible role of leptin in hematopoiesis and reproduction. Nat Med 1996;2:585-9. 
9 Chehab FE, Lim ME, Lu RE. Correction of the sterility defect in homozygous obese female mice by treatment with

10 Barash IA, Cheung CC, Weigle DS, et al. Leptin is a metabolic signal to the reproductive system. Endocrinology 1996 137:3144-7.

11 Chehab FF, Mounzih K, Lu RH, et al. Early onset of reproductive function in normal female mice treated with leptin. Science 1997;275:88-90

12 Ahima RS, Dushay J, Flier SN, et al. Leptin accelerates the onset of puberty in normal female mice. F Clin Invest 1997; 99:391-5.

13 Sierra-Honigmann MR, Nath AK, Murakami C, et al. Biological action of leptin as an angiogenic factor. Science 1998;281:1683-6.

14 Bouloumié A, Drexler HCA, Lafontan M, et al. Leptin, the product of the OB gene, promotes angiogenesis. Circ Res product of the OB

15 Bado A, Levasseur S, Attoub S, et al. The stomach is a source of leptin. Nature 1998;394:790-3.

16 Taga T, Hibi M, Hirata Y, et al. Interleukin-6 triggers the association of its receptor with a possible signal transducer, association of its receptor with

17 Larsen A, Davis T, Curtis BM, et al. Expression cloning of a granulocyte colony stimulating factor receptor: a structural mosaic of hematopoietin receptor, immunoglobulin and fibronectin domains. $\mathcal{F} \operatorname{Exp} M e d$ 1990;172:1559-70. 18 Gearing DP, Thut CJ, VandenBos T, et al. Leukemia inhibitransducer, gp 130. EMBO f 1991;10:2839-48.

19 Lee GH, Proenca R, Montez JM, et al. Abnormal splicing of the leptin receptor in diabetic mice. Nature 1996;379:6325 .
20 Wagner S, Beil W, Westermann J, et al. Regulation of gastric epithelial cell growth by Helicobacter pylori: evidence for a major role of apoptosis. Gastroenterology 1997;113:183647.

1 Wagner S, Enss ML, Cornberg M, et al. Morphological and molecular characterisation of human gastric mucous cells in long-term primary culture. Pflügers Arch 1998;436:87181

22 Kielar D, Clark JSC, Ciechanowicz A, et al. Leptin receptor soforms expressed in human adipose tissue. Metabolism 1998;47:844-7.

23 Gong D-W, Bi S, Pratley RE, et al. Genomic structure and promoter analysis of the human obese gene. 7 Biol Chem 1996;271:3971-4.

24 Ghilardi N, Ziegler S, Wiestner A, et al. Defective STAT signaling by the leptin receptor in diabetic mice. Proc Natl Acad Sci USA 1996;93:6231-5.

25 Baumann H, Morella K, White DW, et al. The full-length leptin receptor has signaling capabilities of interleukin 6-type cytokine receptors. Proc Natl Acad Sci USA 1996;93:8374-8.

26 Murakami T, Yamashita T, Iida $M$, et al. A short form of leptin receptor performs signal transduction. Biochem

27 Loffreda S, Yang SQ, Lin HZ, et al. Leptin regulates proinflammatory immune responses. FASEB f 1998;12:57-65. 28 Brzozowski T, Konturek PC, Konturek SJ, et al. Leptin in gastroprotection induced by cholecystokinin or by a meal. Role of vagal and sensory nerves and nitric oxide. Eur $\mathcal{F}$ Pharmacol 1999;374:263-76.

29 Kaplan LM. Leptin, obesity, and liver disease. Gastroenterology 1998;115:997-1001.

30 Ballinger A. Gastric leptin. Gut 1999;44:153-4. 